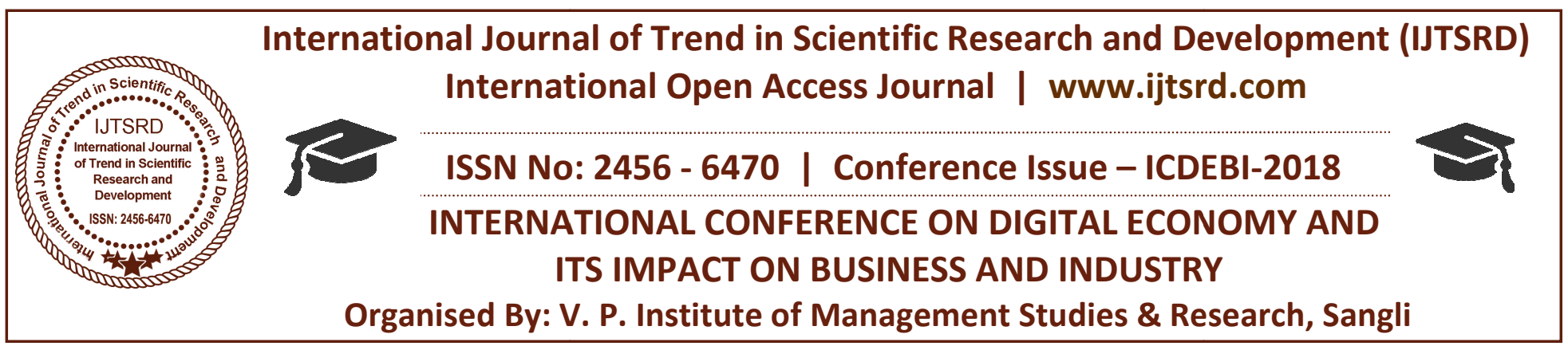

\title{
A Study on Digitalization in Education Sector
}

\author{
Dr. S. J. Jadhav ${ }^{1}$, Mr. Shyamsingh V. Raghuwanshi ${ }^{2}$ \\ ${ }^{1}$ Associate Professor \& HOD, Department of Commerce, \\ Shri Datta Arts \& Commerce College, Hadgaon, Maharashtra, India \\ ${ }^{2}$ Research Scholar, Department of Commerce, \\ Pratibha Niketan Mahavidyalay, Nanded, Maharashtra, India
}

\begin{abstract}
Digitalization could be termed as one of the innovation in the sector of education as it highlights the various activities that lead to the modernization of business model or regarding education sector. The term digitalization refers to the conversion of paper mode or typewritten information (text) into the digital form, means encoding it into Zeroes \& Ones so that Computer can store, process, and transmit such information. In the process of digitalization computer is a device which convert encoded information into readable form so that one can make conclusion from the same. The application of digitalization in the education sector leads to learning environment in the 21 st century. It shows all about the replacement of 'old school system' with 'new school system' that boosted digital education. Digitization does not mean just bringing a "Smart School" but to have the development of an efficient learning oriented lectures to be given in the technical manner so as to match with the present scenario.
\end{abstract}

KEYWORD: Education, Digital Education, Digitalized Education \& Economy, e-learning.

\section{INTRODUCTION}

In the present scenario, India has been reached to the topmost destination in the field of education. Indian education system has adopted innovative skills so as to reach the final destination and making progressive approach towards problem oriented phenomenon. In the world of Information Technology there is need to have an innovative idea that represents the scope \& significance of the knowledge and it is all possible when a nation turn into the globalized form of education. Due to application of digital education it has widened the scope and enhanced the application of the same in the world of Information Technology. It shows all when little children watch their favourite cartoons on the device, e-learning with the application of digital technology. It represents explicit knowledge when apply the digital mode of education in the relevant area. All terms associated with the educational field is represented in a digital manner when it is being digitized with appropriate tools \& techniques. The impact of digitalization in educational sector has totally changed the scenario and a teaching process to a very great extent. Technology based education came into existence providing education with technical aspects to both students and educators. Innovation and technology have been predominant in each sector with undergoing vast changes in the past few years. Technology has made everything much easier and faster, leaving no option for various sectors of the economy but to adapt to change or fear to become obsolete. In the scenario of digitalization, the education sector need to have update and innovated with the adequate proportion of techniques. The Weatern education system came into being in India with the British Raj. However, the British have moved and evolved ways of learning, the Indian education system still lags behind. Teaching is still conducted in archaic classrooms with rigid syllabi dominating the curriculum.

Digitalization provides, fluidity to the Indian Education sector by being a supplementary from of the system as it is available to students as per their need. While the traditional educational system has a 
uniform approach, educational technology can be customized as per student's requirements. It can be molded as per the student's capability to understand and imbibe any particular subject. As the world is moving towards digitalization India has no option but to keep pace with it. We know that the traditional educational system in India is here to stay for the long haul and that no one can take away that learning experience. But our education system needs to be dynamic and needs to adapt technology. There is no need to fear a subject like math's as there are fun ways to learn it with the use of Edtech. Today, there are apps to learn languages or any other subject. Hence the significant role of digitalization appeared.

\section{Research Methodology:-}

Looking into the requirements of the study the research design is being applied to adopt descriptive nature. The research study is of descriptive nature. The collection of data was significantly used from Secondary source and published articles extensively used. Various web articles distinctively used.

\section{Objectives of the Study:-}

1. To know the impact of digitalization in education sector.

2. To highlight the emerging trends in education and relevant sectors due to digitalization.

\section{Data Collection:-}

The research paper is based on the secondary source of information. The required data is extensively used or applied in order to prepare a research paper, as it is in the descriptive nature.

\section{Impact of Digitalization on Education sector:-}

The prevalence of technology affected many areas of society in a positive manner, including education. Modern day students not only to have computers to help them with their schoolwork or academic activities, they also use the internet for research while teachers use technology to enhance their lessons.

1. Due to the digitalization, students are helped to access with the Internet easily \& quickly as it helps them to work better with the academic activities. It shows an indication of having pace of Indian Education System with the globalized scenario.

2. Digitalization help to set up e-library by providing computer lab in the school and colleges, as traditional libraries are outdated. It helps to eradicate hurdles arising in the way of research activities.

3. Due to evolution of digitization it enables to video conferencing when schools in different part of the state, country or world connect, students can meet their counterpart without leaving the classroom.

4. In the era of pre-digitization students tend to enroll through distant courses, called as correspondence courses at colleges and universities. To the contrary, in the digitization era student would receive course details through the mail and would be required to mail assignments to his teacher at the educational institution. Technology is being thankful for the easily accessibility towards the enrolment for various courses offered at distinct level.

5. The limitations regarding resources and budget has been eliminated due to the evolution of technology as the technical devices such as internet, web tools assist students in distinct mode. When school is unable to send its students to the field, technology could enable to attend the web seminar and it is all possible due to the technology and innovative tools.

6. By providing computers in each \& every classroom teachers enable students to learn digitally in the form of correction in spelling, grammatical mistakes, removal of repeating words etc. it creates accuracy in the field of educational environment.

\section{REFERENCES:-}

1. https://www.researchgate.net/publication/2163613 64_Impact_of_Digital_Technology_on_Educ

2. https://www.indiatoday.in/educationtoday/featurephilia/story/digital-education1027965-2017-08-08

3. https://www.entrepreneur.com/article/302680

4. https://smallbusiness.chron.com/five-positiveeffects-technology-education-31222.html 